\title{
Review-artikel: Alexandra Maryanski om Durkheim og religionens oprindelse
}

\author{
Om Alexandra Maryanski, Émile Durkheim and the Birth of the Gods, \\ Routledge 2018, 341 s., £26,39 (paperback).
}

Maryanskis bog om Durkheim er vigtig. Vi anbefaler at den læses og bruges. Men forud for den egentlige anmeldelse er det passende med to forbemærkninger om forfatteren og hendes relation til Religionsvidenskab ved Aarhus Universitet. Den første om forfatteren: Alexandra Maryanski er sociolog fra University of California, Riverside, som samtidig har en solid kunnen inden for biologisk og kulturel antropologi. I Danmark vil hun nok mest være kendt for bogen On the Origin of Societies by Natural Selection fra 2008, som hun skrev sammen med sin mand, sociologen Jonathan H. Turner. Her anlagde forfatterne en generel bio-kulturel, evolutionær forklaring på menneskelige samfunds, og herunder og ikke mindst religionens, forandringer igennem historien. Her blev givet et bud på en fortælling om og en forklaring på menneskeartens udviklingshistorie fra dens oprindelse som en art blandt andre menneskeaber og helt frem til nutiden. Den socio-kulturelle udvikling blev altså forlænget bagud i tid med en udviklingshistorie, der også indbefattede den biologiske udvikling af den menneskelige krop. Et af mange opsigtsvækkende punkter var, at forklaringen på den socio-kulturelle del af historien støttede sig til Herbert Spencer (1820-1903), en forsker der forbandt Darwins biologiske evolutionslære med en teori om kulturel evolution under det berygtede slagsord 'survival of the fittest' - af eftertiden ofte set som indbegrebet af en materialistisk 'evolutionisme' der hjerteløst legitimerede vestlig politisk og økonomisk overherredømme og udbytning. ${ }^{1}$ Spencer blev fortrængt og glemt i den generelle anti-evolutionistisme, der dominerede antropologien og dermed også religionsvidenskaben, i det meste af det 20, årh. Men Turner og Maryanski rehabiliterede Spencer som vejviser for en bio-kulturel evolutionsteori med deres begreb om 'spencersk selektion' eller 'funktionel selektion', der, til forskel for den darwinske, implicerer menneskers bevidste valg mht. adaption til ændrede omstændigheder. ${ }^{2}$ Det er en grundtanke hos dem, at når vi har med intentionelle aktører som

1 Det er dog ikke betydningen hos Spencer, hvilket man ofte har misforstået i den efterfølgende diskussion helt frem til i dag. Hos Spencer refererer udsagnet og tanken specifikt til arters tilpasning til forskellige livsnicher. Det drejer sig ikke om individer.

2 En positiv revurdering af Spencer: David Weinstein, "Herbert Spencer", Stanford Encyclopedia of Philosophy 2019 (https://plato.stanford.edu/entries/spencer/ set 2019-09-30). En klar redegørelse for hovedtanker hos Spencer er omfangsmæssigt overkommelig: Jonathan H. Turner, Herbert Spencer. A Renewed Appreciation, Sage Publications 1985. 
Homo sapiens at gøre, er man nødt til også at inddrage yderligere selektionsmekanismer for at opnå en fuld forståelse.

Et andet opsigtsvækkende punkt i bogen fra 2008 var, at dens religionsforståelse ligefrem og uden forbehold var baseret på Émile Durkheims religionsteori - i religionsvidenskaben ligeledes ofte opfattet som et navn fra forskningshistorien, ikke helt så glemt som Spencer, men dog en fortidig teori, som religionsvidenskaben kan undvære. ${ }^{3}$ Og herfra går der en lige linje til den nye bog om Durkheim og gudernes fødsel.

Den anden forbemærkning: Maryanskis bog er generelt relevant, fordi den er et bidrag til en særdeles omfattende diskussion af Durkheim inden for sociologi og filosofi, hvor Durkheim har en langt mere betydningsfuld position som mestertænker, end den snævrere religionsvidenskabelige forskningstradition kan give indtryk af. ${ }^{4}$ Men bogen er særlig relevant for Religionsvidenskabeligt Tidsskrift, fordi dens emne er central for den evolutionære forståelse af religion og religionshistorie, som ofte er blevet præsenteret og diskuteret $i$ temanumre af og enkeltbidrag til nærværende tidsskrift.

Forbindelsen er ikke kun principiel, men også konkret. Alexandra Maryanski var for nogle år siden sammen med sin mand, sociologen Jonathan Turner, på et længerevarende gæsteforskningsophold ved Afdelingen for Religionsvidenskab ved Aarhus Universitet. Kontakterne her udmøntedes bl.a. i det kollektive værk The Emergence and Evolution of Religion: By Means of Natural Selection (2018), ${ }^{5}$ som ud over Maryanski og Turner også har to Aarhus-forskere som forfattere, Armin W. Geertz og Anders Klostergaard Petersen. Dette giver vor drøftelse af bogen en lidt prekær karakter. For den ene af de to anmeldere her, Klostergaard Petersen, har bidraget til denne bog, mens den anden, Lundager Jensen, er nævnt $\mathrm{i}$ forordet som en (blandt mange) samtalepartnere. Vi er altså tættere på Maryanskis nyeste bog om Durkheim, end anmeldere normalt anses for at burde være. Men omvendt er bogen uden diskussion Maryanskis helt egen. Den er resultatet af hendes forskning alene, og det gælder såvel redegørelsen for den omfattende forskningshistorie op til Durkheims Les formes élémentaires som den forskning i primater, der afslutter bogen. Desuden bør bogen ubetinget diskuteres her i Religionsvidenskabeligt Tidsskrift. Og som samtalepartnere, og som Durkheimlæsere, mener vi også at være tilstrækkeligt kvalificerede til at have en saglig vurdering.

Maryanskis bog har Durkheims store afhandling Les formes élémentaires de la vie religieuse fra $1912,{ }^{6}$ et monument i religionsvidenskabens og sociologiens historie,

3 Et eksempel er Daniel Pals forskningshistoriske lærebog, hvis seneste udgave er Nine Theories of Religion, Oxford University Press 2014; her repræsenterer Durkheim netop 'en teori' på linje med Tylor, Frazer, Freud, Marx etc., alle navne med primært fortidig betydning.

4 Et indtryk af den faglige Durkheim-reception kan man få i Hans Joas, Die Macht des Heiligen. Eine Alternative zur Geschichte der Entzauberung, Suhrkamp 2017, 111-163,

5 Anmeldt af Jonas Svensson i RvT 69, 2019 260-262

6 Maryanski henviser gennemgående til engelske oversættelser, men er ikke konsistent i hvilken. Ved siden af den nutidige standardoversættelse, Karen E. Fields, The Elementary Forms of Religious Life, The Free Press 1995, henviser Maryanski også, uden begrundelse, til den ældre og på nogle punkter forældede fra 1915 (ved J. Swain). Denne mangel er desværre eksemplarisk for bogen, som ville have vundet betydeligt ved ordentlig korrekturlæsning og redigering. Bogen er skæmmet af stavefejl, 
som sit omdrejningspunkt. Udgangspunktet formuleres i indledningen som Maryanskis nysgerrige undren:

I had (...) become incurably curious over why the core premises underlying Durkheim's theory of religion and society now tally with recent findings in neurosociology, the fossil and archeological data, and my own research on great ape societies (s. xv).

Maryanskis hovedtese er, at den teori om religionens oprindelse, som Durkheim formulerede, ikke kun fortsat er interessant og inspirerende, men at den kan underbygges videnskabeligt på en måde, som Durkheim ikke havde kunnet i 1912. Således gør nutidige studier i menneskeaber, et af Maryanskis egne forskningsfelter, det højst plausibelt at de tidligste former for mennesker ville organisere sig på den måde som Durkheim, dengang, for mere end 100 år siden og uden nutidens viden, antog.

Durkheim forudsatte at den tidligste form for menneskelig gruppedannelse var i form af, hvad Maryanski, med et nyttigt sociologisk og primatologisk standardudtryk, kalder "fission and fusion"-cyklusser (s. xvi), dvs. processer hvor et antal individer, der i længere perioder af et år levede adskilt fra hinanden, dvs. kun sammen med nogle andre, i deres søgen efter føde, i kortere tidsrum mødtes og dannede en større gruppe, og at det var tilhørsforholdet til denne gruppe, der gav gruppens individer en særlig identitet. Durkheim antog videre, dels at disse forsamlinger var perioder af intense følelser (primært i kraft af glæden ved at se hinanden), dels at nogle grupper - sikkert oprindeligt mere eller mindre tilfældigt - kunne repræsentere deres særlige identitet ved ydre markeringer, såsom et fælles mødested i landskabet, et visuelt tegn, bestemte særlige genstande, som derfor havde en særlig relevans for gruppens medlemmer, og som de ville kunne huske og identificere sig med, dels at det var sådanne grupper, der bedre end andre var i stand til at bevare deres medlemmers interesse og loyalitet. Det er disse antagelser, Maryanski mener at kunne underbygge med de mange videnskabelige erkendelser om tidlige mennesker og deres biologiske, levende og uddøde, slægtninge, som er kommet til siden 1912. Hvis Durkheim i 1912 'gættede,' så gættede han altså rigtigt.

Bogens centrale del er en kort analyse af Durkheims 1912-bog. Forud går dels en kort og klar indledning, dels en ganske omfattende redegørelse for de mange strømninger og forskernavne i 1800-tallets tidlige sociologi og antropologi, der forberedte og inspirerede Durkheims egen teori - $\mathrm{i}$ forlængelse af eller i polemisk reaktion imod disse. Derpå følger en redegørelse for aktuel forskning i menneskeabers sociale liv, dvs. hvordan individer interagerer med hinanden, i grupper og grupper imellem.

Den forskningshistoriske del er grundig, og den er også godt opbygget. Først gives en kort oversigt over August Comtes og Herbert Spencers første, vigtige tiltag til dannelse af sociologi som et selvstændigt videnskabeligt felt, ledet af et begreb om social evolution (i Spencers tilfælde: social evolution, baseret på etnografisk information, i forlængelse af darwinsk biologisk evolution). Derefter gennemgår hun teorier i 1800tallet om de tidligste former for organisation af menneskelige samfund, dvs. om familier og slægtskab. Der er afsnit om Edward Tylor (om bl.a. animisme), Lewis Henry

uoverensstemmelse i årstalangivelser mellem referencer og bibliografi, og en række andre basale mangler, som en ordentlig redigering burde have fjernet. 
Morgan (om totemisme og teori om 'horden' som den oprindelige sociale organisation, forud for kernefamilien), Johan Jacob Bachofen (teori om oprindelig matriarkat), Henry Maine (de ældste slægtskabsforbindelser var nedstamning igennem mænd), John Ferguson McLennan (oprindelige exogame ægteskabsregler, oprindelige horder før familier, totemisme) og Fustel de Coulanges (religion er et eminent socialt fænomen, som det kan ses i forhistoriske familiers dødekult). Men der er også omtale af Durkheims lærere i det franske miljø: dels Émile Boutroux (videnskabernes hierarki og relative autonomi; fysik, kemi, biologi og åndsvidenskaber har hver en unik, intern logik, der ikke kan udledes af de mere elementære), dels, og nok navnlig, Alfred Espinas (kontinuitet fra biologisk liv til menneskeligt; alle væsener danner samfund: 'intet levende væsen er alene'; menneskelige samfund er konkrete virkeligheder i form af foreninger af individer med bevidsthed: 'et samfund er en levende bevidsthed eller en organisme af ideer').

Denne rekapitulation af forudsætninger for Durkheims Formes élémentaires er nyttig. For mange nutidige læsere af Formes élémentaires vil værket sikkert forekomme massivt ejendommeligt og enestående (ud over, for mange, stimulerende). Forskningshistorien viser, hvor meget i Formes élémentaires der ikke er 'originalt' i betydningen: Durkheims egne originale tanker. Det originale ligger derfor ikke mindst i den måde, hvorpå den skaber en syntese af ideer og teorier, der var vidt udbredte i årtierne op til dets publicering. ${ }^{7}$ Sagt på en anden måde: at læse Durkheim i dag er også at læse sig ind i et mangesidigt og meget produktivt diskussionsfelt i tiden op til Første Verdenskrig. Omvendt var der ingen anden, der skrev et værk som Durkheims. Så hvor præcist lå Durkheims originalitet?

Her, på det præcise midtpunkt i bogen, efter den lange forhistorie og den afsluttende lige så lange indføring i nutidige studier af menneskeaber, er der en svaghed. Selve redegørelsen for hvad Durkheims teori så faktisk gik ud på, fylder overraskende lidt i bogen.

En grund - eller måske grunden - hertil kan være den særlige vægt, Maryanskis forskningshistoriske oversigt lægger på den intense, internationale diskussion af totemisme i tiden op til 1912. Det er sandt, at Durkheims bog også præsenterer sig selv som et bidrag til totemisme-debatten; undertitlen var 'Det totemistiske system i Australien' ('Le système totémique en Australie'). ${ }^{8}$ Men med Maryanski at sammenfatte bogens essens som "a monograph on Australian aboriginals" (s. 169) er misvisende. For det første handler den indlysende nok ikke om australske indfødte generelt, men om et meget smallere felt: om det 'totemistiske system' dvs. australsk religion og klassifikationssystemer. For det andet og vigtigere ligger dens betydning slet ikke i dens

7 Det er også en hovedpointe i Steven Lukes' biografi om Durkheim, hvor en række af de samme tænkere indgår som åndshistorisk forudsætning og inspirationskilde for Durkheim: Steven Lukes: Emile Durkheim: His Life and His Work. A Historical and Critical Study, Stanford University Press 1985 (2. rev. ed., først udgivet Penguin 1973).

8 Undertitlen var udeladt i Swains oversættelse i 1915, som Maryanski noterer s. 179, note 13. Det samme gælder de to nyere oversættelser. I Karen E. Fields fra 1995 er den ikke nævnt i kolofonangivelsen af originaltitlen. I Carol Cosman, The Elementary Forms of Religious Life, Oxford University Press 2002, er den franske titel slet ikke nævnt i kolofonen. Men den er bevaret i franske udgaver såsom Presses Universitaire 1960, 4. ed. Quadrige 1994, og Le livre de poche 1991. 
bidrag til totemismedebatten. Maryanski er sådan set tydelig nok: Durkheims erklærede anliggende "was (1) to describe, and analyze the simplest society known to uncover the origin and foundational religion, and (2) to uncover the foundational categories of human cognition" (ibid.), der jo er noget ganske andet end en monografi om australske indfødte. Men også denne formulering er potentielt forvirrende. For 'grundlæggende religion' kan let tages for at betyde religion som en dimension af et menneskeligt samfund ved siden af andre dimensioner - altså at samfundet var der i forvejen, og at religion så kom til. Og det var netop ikke Durkheims pointe. Religionens oprindelse var for ham det samme som samfundets oprindelse. Eller sagt på anden måde: Samfundet fødtes som religion. Uanset om religion fra moderniteten og frem til nutiden bør betragtes som en sektor i eller dimension ved samfundet ved siden af andre sektorer eller dimensioner (og denne betragtning er jo den normale, ${ }^{9}$ selv om det ikke er så simpelt if. Durkheim), var der intet samfund, if. Durkheim, før der var religion.

Durkheim gik ud fra, at religion altid har eksisteret i menneskelige samfund, og at der er en kontinuitet igennem kulturernes og dermed religionernes historie. Religion er altså ikke 'opstået' eller 'opfundet' flere gange, uafhængigt af hinanden (ligesom fx pattedyr heller ikke er opstået flere gange). Eftersom komplekse samfund er udviklet af ikke-komplekse samfund (dvs. grupper af mennesker uden en statslig eller statslignende organisation), er det nærliggende at antage, at ikke-komplekse samfunds religionsformer var tættere på oprindelsen end senere samfunds religionsformer har været. Totemismen var relevant for Durkheim ud fra en analyse af, hvad der var det bedste bud på en religion, der var tættest på, hvad der kunne antages at være den tidligste og i den forstand oprindelige religion. Men bogens anliggende var at studere, hvad religion var generelt, ikke hvad en bestemt samfundsformations eller bestemte kulturers religioner var, såsom totemisme. Debatten om totemisme var allerede i 1912 ved at lægge sig, delvis affødt af frustration over det tilsyneladende

9 Andre argumenterer for, at en sådan adskillelse mellem forskellige sektorer eller kulturelle sfærer også eksisterede i historiske religioner; men hertil er der i al fald to ting at sige. For det første vil de færreste bestride eksistensen af 'religion' i fx antikken. Religion eksisterede som fænomen; men det er ikke ensbetydende med, at man havde et begreb for 'religion.' Ord som eusebeia og thrēskeia (græsk) eller religio og cultus deorum (latin) med paralleller på andre oldtidssprog betyder ikke det samme, som det moderne religionsbegreb, der først dukkede op i slutningen af det 17. århundrede, og netop forudsatte den begyndende uddifferentiering i forskellige livssfærer. Dertil kommer, at den kulturelle segmentering $\mathrm{i}$ forskellige selvstændige sociale og kulturelle felter som fx spisning, var et hvilket som helst stykke kød ofret til guderne, fordi som minimum (fx pandehåret) en del af dyret var blevet ofret. Det er en sådan forståelse, der ligger bag Webers og Durkheims opfattelse af religion i moderniteten, og som Weber betegnede sækularisering. Se Max Weber "Zwischenbetrachtung: Theorie der Stufen und Richtungen religiöser Weltablehnung," i samme: Gesammelte Aufsätze zur Religionssoziologie vol. 1, Mohr Siebeck 1920, 536-73, 546-54, og Émile Durkheim, Les formes élémentaires de la vie religieuse. Le système totémique en Australie, Felix Alcan 1912, 544-45, jf. 12. For en mere grundlæggende drøftelse af denne problemstilling, se Klostergaard Petersen "Fighting Essentialisations Fosters New Ones: A Review Essay of Daniel Boyarin, Judaism: The Genealogy of a Modern Notion, Rutgers University Press 2019," Journal for the Study of Judaism 2020, 22 sider (under udgivelse), og samme "Examining a Signifiant Flottant. Review of Nickolas P. Roubekas, ed., Theorizing "Religion" in Antiquity, Equinox 2019," Bulletin for the Study of Religion 2020, 14 sider (under udgivelse). 
umulige i at nå til en tilfredsstillende definition af fænomenet, delvis i en stigende afvisning af overordnede og evolutionære teorier til fordel for konkrete empiriske studier af faktisk kultur og religion. Formes élémentaires kom, som Maryanski understreger (s. 162), i dén forstand for sent. Men når Formes fortsat er relevant og inspirerende, er det netop, fordi den ikke er uhjælpeligt bundet op til totemisme-fænomenet. Meget kunne have været afhjulpet, hvis Maryanski i stedet for at stirre sig blind på den religionshistoriske debat om totemisme havde et fjerdeordensbegreb som emblematisme, der fremhæver et af de samme elementer, der ligger i totemismekategorien, men styrer uden om et meget belastet religionshistorisk begreb med en empirisk fundering, der langt fra er sikker.

Derfor er det heller ikke afklarende, når Maryanski formulerer forholdet imellem religion og totemisme, som at "religion was born in totemism" (s. 164). I det omfang totemisme er en særlig form for samfund, må det være omvendt: totemisme 'fødes i' religion. Selv hvis man kunne antage, at totemisme kunne formodes at være den mest oprindelige og enkleste form for samfund - sådan som Durkheim kunne formene (og det næppe kan antages i nutiden) - er det ikke afgørende. Durkheim selv var givetvis ikke uskyldig i forvirringen, jf. undertitlen på hans bog, og måske er den et udslag af en uklarhed i hans egen tænkning. Men hvis det drejer sig om, hvorvidt Durkheims religionsteori er relevant i dag (som det er Maryanskis anliggende, og som forfatterne af dette essay er enige i), har totemismen i virkeligheden ikke noget essentielt med sagen at gøre. Det afgørende er derimod emblemet som symbolsk forankringspunkt for samfundets basale normer, værdier og idealer, kort sagt dets religion. Men denne pointe forsvinder i Maryanskis fascination af en gammel forskningsdebat. ${ }^{10}$

Det er sigende, at det hidtil stærkeste udtryk for en 'neo-durkheimianisme', der er direkte anvendelig i en aktuel religionsvidenskabelig sammenhæng, nemlig Roy Rappaports Ritual and Religion in the Making of Humanity (1999), ${ }^{11}$ ikke engang har 'totemisme' som stikord i registret. Og Hans Joas' Die Macht des Heiligen (2017), der ellers gør en del ud af det, der her omtales som Durkheims totemisme-analyses 'empiriske mangler', lægger sig fornuftigvis fast på, at totemisme-analysen i grunden havde kunne undværes. ${ }^{12}$

Maryanskis optagethed af totemisme-forskningen op til og ind i Durkheims Formes élémentaires er muligvis også årsagen til, at omdrejningspunktet i bogen: redegørelsen

10 Maryanski vender tilbage til temaet s. 179: 'Det er usandsynligt, som det er blevet sagt, at Durkheim kunne have skrevet sin bog uden den australske totemisme' (hvad der jo kan være rigtigt nok fra en Durkheim-biografisk vinkel - i hvert fald ikke til udgivelse i 1912). Men samme side 179f. citeres, med tilslutning, et udsagn om at 'det religiøse aspekt ... er sekundært i forhold til Durkheims basale anliggende ... en forklaring på oprindelsen af social solidaritet'. Dét er til gengæld også synspunktet i nærværende anmeldelse, og det er dét, der også i vores forståelse netop ligger i begrebet om 'religion'.

11 Jf. omtale i RvT 43, 2003, 69-75. - Rappaport nævnes ikke i Maryanskis bog, der, indrømmet, heller ikke vil forlænge det forskningshistoriske opløb til 1912 med en tilsvarende receptionshistorie efter 1912.

12 Joas 2017, 114.127. I samme retning W. Watts Miller, "The Creation and Problematic Achievements of Les Formes élémentaires", in: S-L. Hausner, ed., Durkheim in Dialogue. A Centenary Celebration of the Elementary Forms of Religious, Berghahn Books 2013, 233-256: 254. 
for Durkheims egen teori om religionens oprindelse - efter forskningshistorien og før Maryanskis egne forskningsresultater om menneskeabers gruppeadfærd - efter vores mening paradoksalt nok er det mindst tilfredsstillende i bogen. De vigtigste elementer i Durkheims hypotetiske rekonstruktion er bestemt tilstede. Men den indre sammenhæng imellem en mængde individers sammenkomst, den psykologiske effekt i hvert individ af selve sammenkomsten og den potentielle materialisering af det vagt fornemmede fællesskab i form af ydre 'repræsentationer' fremstår ikke helt klart.

En af grundene er som sagt, at totemisme-temaet forfølges langt ind i gengivelsen, hvor den med fordel havde kunnet være udeladt for at give plads til rekonstruktionen af den virkeligt 'elementære' proces. En anden er formentlig, at begrebet 'samfund' ikke nuanceres tilstrækkeligt for forståelsen. Måske er Durkheim selv (igen) delvis skyldig. Eller måske har begrebet 'samfund' fået fastlagt et betydningsfelt, som det endnu ikke havde på Durkheims tid - med konnotationer i retning af 'samfundsfag' med institutioner, sektorer, juridiske regler, økonomiske mekanismer, politiske procedurer etc. Under alle omstændigheder hjælper det den nutidige læser, hvis ordet 'samfund' i mange sammenhænge oversættes med ord i retning af 'gruppe', 'kollektiv', eller det begreb om 'horde,' som Maryanski med rette selv bruger (bl.a. s. 182. 185). I så fald vil det blive klarere, at det, Durkheim taler om, er gruppe-dannelse og gruppe-persistens i alle tænkelige former og størrelser, og at også familier, vennekredse, foreninger, politiske partier er 'samfund.' Og det ville hjælpe til at undgå den forenkling der ligger i formuleringer som at 'gud er samfundet selv' eller 'gud og samfundet er det samme' (som Maryanski, s. 179. 187). Når Durkheim selv udtrykte sig sådan, var meningen, at guddomme var figurative repræsentationer for de bestemte idealer, som bestemte grupper hyldede: en krigergruppe dyrkede en krigsgud, mødre dyrkede en modergudinde, osv. - og en australsk klan forstod sig selv som konstitueret og opretholdt af bestemte egenskaber som fandtes i bestemte steder i landskabet og som forbandt dem med bestemte arter af dyr og planter og evt. andre typer størrelser.

Hvis man i en nutidig gengivelse af Durkheims tankegang er mere varsom med brugen af ordet 'samfund', kan forholdet imellem religion og samfund også formuleres klarere. ${ }^{13}$ Durkheim selv lagde op til sammenfatninger som "god being only a 'figurative expression' of society" (s. 190). Men hans teori var at (1) uden en 'gud' ville der ikke være noget 'samfund', og (2) uden figurative repræsentationer ville en 'gud' ikke have kunnet fået plads i menneskelige bevidstheder. Det er, hvad der ligger i vores tanke om emblemet, der netop er den figurative repræsentation af gruppens basale normer og idealer. For som sagt mente Durkheim, at samfund og religion opstår som det samme. (Hvilket indebærer at alle samfund, inkl. familier og venskaber, er en slags 'religion'. Derfor giver det god mening at skelne mellem tynde og fede former for religion; men det er ud fra den helt klare præmis, at der netop er tale om et

13 Andre Durkheim-inspirerede forskere som fx Joseph Henrich bruger et udtryk, der er blevet udbredt i moderne moral- og evolutionspsykologi og biologi, groupishness. Det fanger præcist den durkheimske tanke, men det er desværre ikke muligt at overføre til dansk. Se fx Johnathan Haidt, The Righteous Mind. Why Good People Are Divided by Politics and Religion, Vintage Books 2012, og Joseph Henrich, The Secret of Our Success: How Culture Is Driving Human Evolution, Princeton 2017. 
kontinuum: Ingen gruppe, hvad enten vi taler to eller flere, intet samfund uden religion. Durkheims teori var virkelig radikal og kontra-intuitiv).

Maryanskis korte fremstilling af Durkheims teori kommer ikke ind på indordningen af magi under religion (imod Frazer, for hvem magien var et stadie i menneskehedens historie forud for religion). Den nævner heller ikke de afsluttende overvejelser over det problematiske forhold imellem religion og menneskers liv i industrielle nationalstater. At Formes élémentaires inkluderer en form for fundamental-semiotik, vil formentlig ikke gå op for de fleste læsere. Maryanski tangerer problemstillingen s. 190 (med citatet hvordan religiøse kræfter tillægges genstande); men det bliver ikke rigtigt klart, at dette hører til en argumentation for hvordan tegn i det hele taget er blevet mulige. Der er kun antydninger af Durkheims antropologiske centralbegreb 'homo duplex' (altså biologisk krop og kulturelt kodet bevidsthed og dermed også det spændingsforhold, som Maryanski ellers har så fint sans for, nemlig spændet mellem naturlig selviskhed på den ene side og selvopofrende og delvist attraktiv fællesskabstilslutning på den anden) ${ }^{14}$ eller at effervescens - den emotionelle løftelse i mødet med andre mennesker efter lange perioder af relativ isolation - bevirkes af mimetiske reaktioner. ${ }^{15}$ Dermed underspilles, at Durkheims 'sociologi' reelt var en psykosociologi, og at den altså henhører lige så meget under psykologi (kognitiv såvel som emotionel) som under 'sociologi' i nutidig forstand. En fremhævelse af dette ville endda kun have styrket Maryanskis overordnede formål med bogen, for der er her en direkte kontinuitet imellem Durkheims og hendes egne ræsonnementer.

Forlader vi nu for en stund Durkheim og bevæger os over til bogens anden hoveddel, om sammenhængen mellem menneskets socialitet og dets evolutionære baggrund blandt de øvrige menneskeaber. Forbindelsen er, som vi allerede pointerede i indledningen meget klar. Maryanskis tanke er, at Durkheims generelle psyko-sociale teori om menneskelige gruppers og religioners oprindelse lader sig yderligere underbygge af nutidig viden om dels vor fjerne evolutionære fortid, dels af primatologisk indsigt i de øvrige nulevende menneskeaber foruden os selv - det gælder orangutanger, gorillaer, og i særlig grad chimpanser og bonoboer. Det er ikke mindst i denne sammenhæng, bogens helt store fortjeneste ligger. For det første har ingen andre forsøgt noget lignende. For det andet kommer der i disse år på næsten ugentlig basis ny viden om vore nærmeste fætre og kusiner blandt de øvrige menneskeaber, som gør

14 Det er denne modsætning, der ligger bag Durkheims grundlæggende askeseforståelse. Se Klostergaard Petersen, "A New Take on Asceticism: Asceticism as Training and Secession Suspended between Individuality and Collectivity," Numen 65 (5-6), 2019, 465-98, 473-77.

15 I dag vil man kunne yderligere underbygge Durkheims tanke biologisk ved inddragelse af den betydning, spejlneuroner, udløst gennem mimetiske handlinger, har for styrkelsen af prosocialitet mellem enkeltindivider. Og det er netop grundlæggende biologisk og kan derfor heller ikke reduceres til mennesker, men kan påvises også hos en lang række andre dyr. Se Vittorio Galese og Corrado Sinigaglia, "Embodied Resonance," in: Albert Newen, Leon de Bruin og Shaun Gallagher, eds., The Oxford Handbook of 4E Cognition, Oxford University Press 2018, 417-432, 417-20, der har de væsentligste henvisninger til den nyeste litteratur om emnet. For et grundlæggende skeptisk synspunkt på spejlneuroners betydning, se Robert Sapolsky, Behave, The Biology of Humans at Our Best and Our Worst, Penguin 2017, 437-42. 
spørgsmålet yderligere relevant, fordi det, når det gælder så centrale menneskelige elementer som kultur, religion og livsnicher, rykker os yderligere tæt på hinanden.

Hovedtanken i Maryanskis biologiske underbygning af Durkheim bygger på kladistiske analyser. Det er den type taksonomiske undersøgelser, mange kender fra lingvistik, botanik og zoologi, hvor grendiagrammer viser de enkelte sprogs eller arters oprindelse og udskillelse fra andre. Ud fra eksisterende arter kan man kladistisk rekonstruere tidligere arter og derved nå til dybere forståelse af, hvorfor sprog eller som her menneskearten har udviklet sig, som den har gjort. Samtidig gør metoden det muligt at operere med en tæt relateret kontrolgruppe, der ved sammenligning med fokusgruppen tydeliggør tidspunkterne for vigtige ændringer. Derved kan man komme tilbage til fælles ophav, som er afgørende for at forstå den efterfølgende udvikling. Målet i bogens anden del er på grundlag af rekonstruktion af fælles hominidt ophav (kapitel 12-17, s. 194-303) at forstå den hominine udvikling (dvs. særligt den post-australopithecine udvikling). ${ }^{16}$ Men hvor efterlader det Durkheim?

Slutsætningerne i Formes lyder: 'Det er nødvendigt at prøve hypotesen, også metodisk på baggrund af kendsgerninger (au contrôle des faits) at prøve den, som det lader sig gøre. Det er det, vi har forsøgt' (Formes 2007, 624). Maryanskis originalitet ligger ikke mindst $\mathrm{i}$ at tage Durkheim på ordet og forsøge ved inddragelse af primatologi, evolutionsteori og kladistik at afprøve hans tese. Dermed kan hun også afvise en række af de indvendinger, der gennem tiden er blevet fremført mod ham. Nogle beror på misforståelser. Men det betyder ikke så meget, hvis de først har vundet hævd og er blevet kulturelle sandheder, der kan rettes mod hans tænkning. Derfor er godt, at Maryanski ikke alene tilbageviser flere af dem som misforståede, men også har mod til at påpege de steder, hvor der faktisk er problemer hos Durkheim. Hun fremhæver ti forhold: 1) Teorien hører hjemme i en forældet evolutionstænkning i det 19. århundrede; 2) samme århundredes måde at skelne mellem simple og komplekse samfund er endegyldigt opgivet; 3 ) totemismebegrebet og dets underliggende teori er definitivt miskrediteret; 4) tanken om enkeltklanen er aldrig dokumenteret i nogen befolkningsgruppe; 5) forestillingen om at religion har sin oprindelse i fremkomsten af det hellige og individernes kultiske sammenkomst lader sig hverken falsificere eller verificere; 6) relationen mellem exogami, totemisme og incestforbud er endnu ikke afgjort; 7) ideen om at slægtskab begyndte med et matrilineært system, er tvivlsom; 8) Durkheims tanke om en grundlæggende universel klassificering af alle ting som hellige og profane er omstridt; 9) forestillingen om horden som den basale menneskelige sammenslutning står fortsat til drøftelse; 10) tanken om kernefamilien som naturlig enhed eller fundamental menneskelig organiseringsmåde er et åbent spørgsmål (s. 196f.).

Man kan diskutere tyngden i de enkelte punkter. Det er svært at se berettigelsen af punkt et, to, fem og otte, når Durkheims modstandere ikke føler sig kaldet til at fremføre argumentation for kritikken. At påpege at et standpunkt hører hjemme i en

16 Der er ikke videnskabelig konsensus om brug af hominide- og homininbegrebet, hvorfor de ofte sammenblandes eller bruges i flæng. Vi anvender begreberne, som det er gængs i dele af den biologiske evolutionslitteratur, hvor hominider henviser til alle de store menneskeaber og deres fælles ophav, medens homininer alene refererer til Homo-linjen. 
bestemt åndshistorisk sammenhæng, er ikke nogen kritik, medmindre man viser, at det netop derfor er problemfyldt. Det ændrer dog ikke ved, at punkterne alle er nogle, der ofte som automatreaktion fremføres som afvisning af Durkheims fortsatte relevans. Vi bifalder derfor, at Maryanski går i rette med kritikpunkterne og drøfter dem i lyset af Durkheims ideal for ordentlig sociologisk metode, at den dels er historisk funderet, dels objektiv.

Kapitel 12 er en kort gennemgang af den menneskelige udviklingshistorie fra udskillelsen af den proto-hominine gren fra chimpanser for ca. fem til syv millioner år siden og frem til Homo sapiens' hulemalerier for 20.000 år siden. Maryanski er optaget af væsentlige anatomiske forandringer, fremkomsten af den tidligste form for kumulativ kultur (acheuliansk kultur for 1.7 millioner år siden), brug og kontrol med ild (antagelig en million år siden), begravelsesskikke og forskellige former for kunst. Tanken er, at fossiler, molekylær og arkæologisk dokumentation giver os de eneste data, vi har til menneskelig evolution og kultur (s. 209). Men der er en yderligere pointe, som for alvor bliver klar i de to følgende kapitler. I kunsten finder Maryanski elementer af den durkheimske effervescens, fordi den både er følelsesfremkaldende og indeholder et kognitivt element. Atter dukker det problematiske totembegreb op, hvor Maryanski kunne have gjort sig selv en tjeneste, hvis hun havde nøjedes med at tale om emblematisering.

I kapitel 13 om den hominide sociale arv drøfter Maryanski de øvrige menneskeaber og den måde, hvorpå de organiserer sig. Kapitlets præambeltekst sammenfatter den hovedpointe, vi allerede har fremhævet i Durkheims tanke om mennesket som homo duplex, spændt ud på et kontinuum mellem biologi og kultur, selviskhed og fællesskab. Teksten er interessant, fordi den er fra den tidlige forelæsningsrække om moralsk uddannelse fra 1902-03, et tiår før Formes. Også her pointerede Durkheim spændingen mellem selv og fællesskab: 'Ja, den store forhindring ved denne sammensmeltning (fusion), ved dette fællesskab mellem indre bevidstheder og en fælles bevidsthed, er den individuelle personlighed. Jo mere anklaget den personlighed er, jo skarpere konturerne er, desto mere vanskeligt er det at få den til at smelte sammen med noget andet end den selv. For at opleve glæden ved at sige 'vi', er det vigtigt ikke at finde alt for meget behag i at sige ' jeg'. ${ }^{17}$ Spændingen mellem selv og gruppe løber som rød tråd gennem fremstillingen af de øvrige hominider, ligesom Maryanski viser, hvordan det fra begyndelsen var Durkheims hovedspørgsmål (s. 212f.). ${ }^{18}$ Hun sammenfatter det med to spørgsmål: 'Hvor naturligt sociale er mennesker? Hvordan

17 Émile Durkheim, L'éducation morale, Quadrige/PUF 1972 (1925), 204. Omvendt kan Durkheim umiddelbart forud for at have pointeret spændingen mellem selv og fællesskab også fremhæve kollektivets positive betydning: 'Der er en glæde ved at sige vi i stedet for jeg, fordi enhver, som kan sige vi, mærker bag sig en støtte, en kraft, som han kan regne med, en kraft meget mere intens end den, isolerede individer kan overgive sig til. Og denne glæde er endnu større, når vi kan sige vi med sikkerhed og overbevisning' (s. 203).

18 Steven Lukes viser i sin Durkheim-biografi 330-353, hvordan forståelsen er knyttet til Durkheims engagement i Dreyfuss-affæren og hans bekymring for, hvordan der kan skabes og fastholdes sammenhængskraft i det industrielle samfund, der truer med at isolere individet. Denne forståelse er yderligere uddybet i Marcel Fournier nyere biografi, Émile Durkheim, Fayard 2007, 365. 
er vi kommet dertil?' (s. 213). Det fører os direkte til spørgsmålet om, hvordan en religiøs institution kunne opstå ud af et ikke-institutionaliseret miljø.

Hvis man ser på aber (engelsk monkeys), er de betydeligt mere sociale end menneskeaber (engelsk apes); men genetisk er de ikke særligt interessante i forhold til mennesker, der udgør en blandt andre menneskeabearter. Omvendt er menneskeaber kendetegnet ved svage sociale bånd begrænset til moder-datter- og moder-søn-relation. Derfor kan man kladistisk slutte, at det samme må gælde vor fælles formoder/fader for ca. 6,5 millioner år siden. Chimpanser lever ganske vist i fission-fusion-grupper af 50-100 individer; men de er, som navnet angiver, meget lidt stabile og varige. Så hvordan er vi som moderne mennesker blevet så sociale, som vi er, når socialiteten ikke stikker særlig dybt i vor genetiske natur? Selvom Durkheim ikke havde den viden til rådighed, som vi har i dag, forstod han, at vi i forhold til basalbiologi er væsentligt mindre sociale og langt mere individualistiske, end det almindeligvis antages. Maryanski bruger ikke udtrykkene ultra- vs. eusocialitet, men det kunne hun have gjort. Det er den biologiske betegnelse for forskellen mellem genetisk programmeret (f.eks. bier og myrer) og biokulturelt funderet socialitet. ${ }^{19}$

Det er en grundlæggende tanke i al evolution, at intet opstår ud af intet. Nye træk bygger på eksisterende elementer. Det er også hovedtanken bag Robert Bellahs programmatisk formulerede maksime: "Nothing is ever lost." ${ }^{20}$ Samme idé finder man hos Durkheim: 'Intet opstår ud af intet' ("Rien ne vient de rien," jf. Robertson Smiths tanke om religiøs evolution som forbundne geologiske lag). ${ }^{21} \mathrm{I}$ den forbindelse er det centrale spørgsmål: Hvad kan menneskelig socialitet evolutionært bygge på, hvis vi genetisk ikke er synderligt sociale? Vor socialitet kan ikke være opstået ud af det blå? Så hvilke biologiske elementer ligger til grund for den voldsomt accelererende udvikling, der har været over de sidste 4500 år (de tidligste større bydannelser) og i et lidt større perspektiv 11.000 år (de tidligste former for landbrug), ${ }^{22}$ frem til de enorme fællesskaber, vi har i dag med f.eks. tre kinesiske byer med over 22.5 millioner mennesker? ${ }^{23}$ Intet samfund kan ifølge Durkheim tænkes uden religion, så hvordan og hvorfor opstod religion, hvis intet opstår ex nihilo? Maryanski hævder for, at 'alle anstrengelser til trods kunne Durkheim ikke andet end til sidst at foreslå en dristig gisning om religionens og samfundets oprindelse' (s. 211):

19 Klostergaard Petersen, “Den nøgne hud: Om rødme, følelser og fællesskab," Slagmark 80, 2020, 31$51,36$.

20 Robert N. Bellah, “Nothing Is ever Lost. An Interview with Robert Bellah," The Immanent Frame. Secularism, religion, and the public sphere SSRC September 14, 2011. Tilgængelig pa: https://tif.ssrc.org/2011/09/14/nothing-is-ever-lost/ (sidst set 10.01.20).

21 Émile Durkheim, De la division du travail social. Thèse présentée à la Faculté des lettres de Paris, Felix Alcan 1893, 156, jf. også det parallelle udsagn Formes élémentaires, Felix Alcan 1912, 321-22. William Robertson Smith, Lectures on the Religions of the Semites. The Fundamental Institutions, A. and C. Black $1927,24$.

22 Se befolkningsestimater i James C. Scott, Against the Grain: A Deep History of the Earliest States, Yale University Press 2017, 6.

23 For den fortsatte uafvendelighed i byudvikling, se Monica L. Smith, Cities. The First 6000 Years, Penguin Random House 2019, 227-42. 
Durkheim was convinced that religious sentiments originated when nomadic food collectors met up on occasion and detected an intangible aura that seemed to surround them - an energy force that seemed to transcend all their individual selves. Reacting to this emanation, they responded by projecting these effervescing sensations onto visible, tangible things - plants and animals or their symbolic representations-resulting in the birth of religion and an awareness of society itself (s. 211).

Maryanski argumenterer, at vi i dag med primatologien ikke alene kan dokumentere, at Durkheim havde delvist ret, men også at hans opfattelse har dybere biologisk evidens, der underbygger den grundlæggende evolutionære tanke: Intet opstår ud af intet. Hos chimpanser kan vi se træk, der peger frem mod fremkomsten af religion i Homo-linjen. Det er emnet for kap. 14.

Hos chimpanser finder vi territorialmarkering og dermed en begyndende bevidsthed om 'symbolsk' tilhørsforhold til en bestemt gruppe, håndhævelse af tabu mod migration af hanner til nabogrupper, grooming-adfærd, der fastholder socialt fællesskab, emotionel forbundethed inden for gruppen og forholdsvis stærk kulturel transmission over tid (redskaber) - træk, der antagelig understøttes af nyere studier, der antyder protoreligiøs, rituel adfærd hos chimpanser. ${ }^{24}$ Maryanski hævder endvidere, uden dog at dokumentere det, at tilsvarende, om end svagere varianter af samme træk, findes hos orangutanger og gorillaer (s. 240). På det grundlag kan hun fastslå og dermed underbygge den durkheimske opfattelse, at andre nulevende aber samt vor fælles formoder/fader havde en, om end svagt funderet, samfundssans (sense of community): "Supposedly, given the right triggers, great apes and humans are primed to experience an emotionally-driven extramundane entity-a property of the social mind" (s. 240f.). Det fører til spørgsmålet, hvilke sansemæssige byggeklodser denne fælles kognitive egenskab udgøres af.

Det er temaet for kap. 15 om det hominide sind og selvet, hvor Maryanski ikke mindst bruger George Herbert Mead som teoretisk linse. Der er primatologisk dokumentation for, at chimpanser har en veludviklet form for evne til at aflæse andres intentionalitet (theory of mind, eller som man i forlængelse af Mercier og Sperber kan foretrække at kalde det, mind-reading, for at undgå forestillinger om en art iboende intellektuel eller teoretisk evne). ${ }^{25}$ De er også i stand til at genkende sig selv i et spejl, medmindre de er opdraget i social isolation fra andre chimpanser. De formår at indgå i rolleovertagelse; men har de også potentiale for symbolsk kommunikation og fællesskab med signifikante andre, der former barnets sociale og emotionelle behov? Netop de to spørgsmål, Mead identificerede som afgørende for en egentlig selvforståelse (s. 251). Ser man på forskellige former for chimpansekommunikation fra vokalisering, gestik, lingvistiske evner og beherskelse af kunstigt sprog, argumenterer Maryanski for, at chimpanser har samme evne som moderne mennesker, om end i en

24 Se Hjalmar S. Kühl, Ammie K. Kalan, Christophe Boesch et al., “Chimpanzee accumulative stone throwing," Scientific Reports 29.02. 2016 - tilgængelig på: https://www.nature.com/articles/srep22219 (senest set 10.01.2020).

25 Hugo Mercier og Daniel Sperber, The Enigma of Reason, Harvard University Press 2017. 
betydelig mere simpel form, hvilket fører til konklusionen: "As our closest living relatives they offer an excellent template to meet the guidelines laid out by Durkheim" (s. 257).

Maryanski er nu næsten ved vejs ende, hvor den indhøstede viden om vor fælles hominide formoder/fader og om nulevende chimpanser kan bruges til at teste plausibiliteten i den durkheimske religions- og samfundsopfattelse. Det sker i kap. 16, hvor Maryanski argumenterer for, at Durkheims idé om horden slet ikke var så fortænkt, som mange har villet gøre den til. Ser man på orangutanger og især chimpanser, kommer vi tæt på horden: "Both are composed of stand-alone self-dependent food collectors. Stable groupings are unknown (except for mother with dependent offspring), and both apes evidence a fission-fusion pattern where individuals wander about by themselves or voluntarily join temporary parties (albeit, for orangutans sporadically" (s. 262). Dermed har hun afvist yderligere et af de ti kritikpunkter, som er blevet fremført som udtryk for det spekulative hos Durkeheim. På grundlag af Durkheims inspiration fra Espinas' Des Sociétés animales, étude de psychologie comparée (1878) og hans tanke om, at her begyndte sociologien, hævder Maryanski, at han formentlig ville have fulgt hendes argumentation, hvis han havde haft samme data til rådighed (s. 262). Et andet kritikpunkt fremført mod Durkheim er hans idé om forbindelsen mellem exogami, matrilinearitet og incestforbud. Det er svært at vurdere, men, hævder Maryanski, skønt Durkheims tanke om den incestuøse horde var forkert, så var det rigtigt set, at slægtskab ikke er nøglen til social organisering i tidlige hominine fællesskaber (s. 265). Kernefamilien er en senere adaption, der forudsætter horden.

Chimpanser har theory of mind (ToM) eller evne til at aflæse andres intentionalitet. De kan indgå i rolleskifterelationer, ligesom de kan genkende sig selv i et spejl og har udviklet rig brug af gestik. Der er også begyndende evidens for, at de har noget, man kunne betegne som protosymbolicitet, hvis Kühls, Kalans, Boesch' studie viser andet og mere end underholdende leg: alt sammen noget, der demonstrerer, at chimpanser har en basal, om end rudimentær, selvforståelse. Mere væsentligt er, at de ud over selvbevidsthed også har en elementær sans for at være et kollektivt selv. Derfor giver det ifølge Maryanski mening med Mead at tilskrive dem en, omend simpel, så dog bevidsthed om den generelle anden og dermed forståelse af fællesskabets perspektiv, normer og regler. Derfor er det ikke så absurd, som det umiddelbart lyder, at hævde, at chimpanser udviser en begyndende form af Durkheims tanke om mennesket som homo duplex: "While endowed by nature with a rugged individualism, it seems clear that chimpanzees have a dual identity - a personal self and a collective self. So they are individualists but not exclusive individuals because they experience and see themselves as part of a fluid and dispersed community of other selves" (s. 269).

Dermed er Maryanski næsten argumentativt hjemme. Hun har vist, at de grundlæggende byggeklodser til vore betydeligt udvidede og mere stabile fællesskaber findes hos vore nærmeste slægtninge: chimpanserne. Der eksisterede således evolutionære elementer, som den særligt hominine udvikling gennem naturlig selektion - og 
senere suppleret af andre selektionsmekanismer, men fortsat drevet frem gennem naturlig selektion - kunne videreudvikle: ${ }^{26}$ Durkheims “... premises on individualism, horde, lack of kinship in protohuman societies, and female-biased "exogamy" are overall supported, with some modification to be sure (which he anticipates)" (s. 273). Men en ting er at finde støtte for Durkheims præmisser - noget andet er, om de også kan bruges til at besvare det centrale spørgsmål: Udviser chimpanser et forstadie til menneskelig religiøsitet?

Det er slutkapitlets spørgsmål: Secrets of the Totem. Lader vi det problematiske totembegreb falde og erstatter det med emblem og emblematisering, der ikke har samme religionshistoriske problemer knyttet til sig (se Maryanskis totemdefinition, s. 293, og hendes forsvar for begrebet, s. 280-93), styrker det argumentationen. Hun peger i den forbindelse på karnevalistisk adfærd hos chimpanser, som flere primatologer har noteret, ligesom hun henviser til det føromtalte studie af Kühl, Kalan, Boesch, der muligvis dokumenterer ritualiseret adfærd blandt chimpanser i forbindelse med territorialmarkering og, hvis det er tilfældet, ${ }^{27}$ en form for protosymbolsk bevidsthed om fællesskabsdelagtighed (den er protosymbolsk, fordi den ikke er sprogligt formidlet):

The emotions that accompany the displays are suggestive of some sort of spiritual ritual directed at forces perceived to exist, but we are not privy to what chimpanzees believe or don't believe. But they clearly display the ritual side of this equation marking religion, which means that as the hominin brain began to grow rapidly with later Homo erectus the other half of the equation - thoughts and cognitions about a supernatural realm, however simple - would make such ritual sacred and spiritual at the dawn of human evolution (s. 278).

Det giver god mening at tænke Durkheim i den sammenhæng; men man er også nødt til at sige, at det studie af Kühl, Kalan, Boesch' studie, som Maryanski lægger til grund for størstedelen af sin argumentation, er omgærdet med betydelig usikkerhed, ligesom der ikke på nuværende tidspunkt findes andre studier foretaget $\mathrm{i}$ andre chimpansepopulationer, der kan understøtte det. Nået i mål med sin argumentation stiller Maryanski spørgsmålet, om chimpanser totemiserer (bedre: 'emblematiser')? Hun hævder ikke, at chimpanser har religion; men det har heller ikke været bogens argument. Det drejer sig alene om, skønt det er væsentligt nok, at intet kommer ud af intet. Hvilke evolutionære byggeklodser hviler menneskelig socialitet og religion på, hvis de ikke kunne opstå ud af det blå? Her er Maryanskis tankevækkende pointe, at 'en

26 Disse andre mekanismer har ikke med fremkomsten af kumulativ kultur at gøre, hvor kultur - forstået som alle former for ikke genetisk transmitteret læring - blev en afgørende del af den menneskelige biologi. Se særligt Robert Boyd, A Different Kind of Animal: How Culture Transformed Our Species, Princeton University Press 2018, 9-62, og Kevin Laland, Darwin's Unfinished Symphony: How Culture Made the Human Mind, Princeton University Press 2017, 208-33. Om betydningen af de øvrige selektionsmekanismer og deres specifikke rolle, se Turnet et al., The Emergence and Evolution of Religion: By Means of Natural Selection.

27 Det er fortsat usikkert, hvad chimpansernes slag med sten på hule træstammer præcist betyder, ligesom det heller ikke er klart, om de stenbunker, der hober sig op for foden af træerne, i forlængelse af chimpansernes trommelyde på træerne, af chimpanserne tillægges særlig ‘hellig' betydning. 
selvidentitet, et afgrænset og delt fællesskab og en sans for fællesskabet er tilstrækkeligt til at bygge bro over de kløfter, som er nødvendige for social sammenhæng og stabilitet i en dynamisk, social fission og fusionsstruktur blandt chimpanser' (s. 297). Det er emblematiseringens evolutionære begyndelse, som fremkomsten af egentlig religion (forstået som en grundlæggende følelsesinvestering i et emblem, der samler gruppens identitet udmøntet i fælles værdier, idealer, normer og regler) blandt homininer på et langt senere tidspunkt kunne bygge videre på og udvikle til det, vi kender som institutionaliseret religion. Dermed har Maryanski påvist, hvordan Durkheims grundlæggende antagelser i dag støttes af aktuel hominide- og homininforskning. De ti kritikpunkter, hun anfører i kap. 12, kan stort set alle afvises, hvis man har mod til også at tolke Durkheims tanker om oprindelsen til menneskelige fællesskaber og religion i lyset af aktuel viden fra livs- og adfærdsvidenskaber (s. 331). Durkheim havde af gode grunde ikke de empiriske data til rådighed, vi har i dag; men han ønskede netop, som han gav udtryk for i slutsætningerne i Formes, at hans forståelse metodisk stringent løbende skulle prøves på de kendsgerninger, der var til rådighed. Det har Maryanski gjort på fornem vis.

Hun har et imponerende overblik over det meste af den aktuelle hominide- og homininforskning og formår at forbinde den med en klar læsning af Durkheim, som samtidig dokumenterer betydelig fortrolighed med den historiske og forskningshistoriske baggrund for hans tænkning. Skulle man anføre et enkelt kritikpunkt mod hendes grandiose sammentænkning af indsigter fra forskellige discipliner, er det hendes stærke fokus på chimpanser. Nu er der ganske vist ikke - af forskellige grunde, der primært skyldes den sene opdagelse af bonoboer som selvstændig art - lige så omfattende forskning i dem, selvom tingene begynder at ændre sig. Men bonoboer ligner det moderne menneske væsentligt mere end chimpanser og har sandsynligvis undergået en evolution, der på nogle punkter er tættere på Homo sapiens. Begge ser ud til at have undergået en biologisk drevet domesticering med væsentlige parallelle anatomiske og kognitive og adfærdsmæssige forandringer til følge. Hvor chimpanser er reaktivt voldelige, er det anderledes hos det moderne menneske og bonoboer. ${ }^{28} \mathrm{Vi}$ er ikke fredelige, hvad enhver kan forvisse sig om ved blot at tænke på de sidste 35 års europæiske historie; men der er meget stor forskel på proaktiv og reaktiv aggressivitet. Samme fænomen finder vi hos bonoboer. Derfor er det sandsynligt, at de har en mere udbygget fællesskabsfølelse end chimpanser. Om de har stærkere protoreligiøs adfærd, ved vi ikke; men det er et felt, der i den grad trænger til at blive undersøgt. Og det ville have været interessant, hvis Maryanski i højere grad havde skelnet mellem de to pan-arter og ikke fokuseret eksklusivt på chimpanser.

Denne bemærkning ændrer dog ikke ved betydningen af Maryanskis bog. Vi har givet den en udførlig omtale, fordi vi opfatter den som et centralt religionsvidenskabeligt værk. Ikke alene gør den en af fagets betydningsfulde klassikere nutidig helt relevant og uomgængelig. Det har vi i Aarhus-miljøet aldrig anfægtet; men det er

28 Det er hovedtanken i Richard Wranghams meget tankevækkende bog, The Goodness Paradox: The Strange Relationship Between Virtue and Violence in Human Evolution, Pantheon Books 2019, 24-46. 87111. For en præsentation af hovedtanker i bogen, se Anders Klostergaard Petersen, "En tæmmet hidsigprop," Weekendavisen. Ideer. 18 1.05. (2020), 12-13. 
bekræftende, når andre også kan se det. Den viden, Maryanski fremfører om hominider og homininers sociale strukturer, er imidlertid også vigtig for enhver, som vil beskæftige sig med fremkomsten af religion og dens persistens og relationen mellem religion, gruppedannelse og fællesskabsfølelse. Og det er netop kernen i den durkheimske tænkning.

Hans J. Lundager Jensen, professor, dr.theol. Anders Klostergaard Petersen, lektor, cand. theol. Afdeling for Religionsvidenskab, Aarhus Universitet 